\title{
British attitudes towards the United States since 1941
}

\author{
Clive Webb ${ }^{1} \cdot$ Robert Cook $^{1}$
}

Published online: 29 June 2020

(C) The Editor of the Journal 2020

On Monday June 3, 2019, President Donald Trump arrived aboard Air Force One at Stansted Airport on his first official state visit to Britain. He received a ceremonial welcome in the gardens of Buckingham Palace followed that evening by an elaborate banquet hosted by Queen Elizabeth II. Having held a private meeting the next day, President Trump and Prime Minister Theresa May appeared for a joint press conference at the British premier's Chequers country residence. With the visit timed to coincide with the 75th anniversary of the D-Day landings, the event provided the opportunity for both politicians to extol the alliance between their nations that had not only helped to win the war but also continued to maintain global peace. 'Our special relationship', affirmed Trump, 'is grounded in common history, values, customs, culture, language, and laws. Our people believe in freedom and independence as a sacred birthright and cherished inheritance worth defending at any cost'. ${ }^{1}$

The pomp and ceremony surrounding the presidential visit appeared to symbolise the singular nature of a partnership rooted in not only mutual self-interest but also more profound ties of identity. Yet royal gun salutes did not provide the only soundtrack to the tour. An estimated quarter of a million protesters took to the streets of London in a potent display of grassroots hostility to the president. The most iconic symbol of public opposition was an orange balloon depicting the president as an overgrown baby that floated in the summer sky above the nation's capital. ${ }^{2}$

The evident tension between Britain's ruling elite and broad sections of the public contrasted sharply with another presidential visit that occurred six decades earlier. On August 27, 1959, President Dwight D. Eisenhower arrived in Britain on a tour that included visits to Prime Minister Harold Macmillan at Chequers and Queen Elizabeth II at Balmoral. His arrival in Britain was cause for concern among

\footnotetext{
${ }^{1}$ Remarks by President Trump and Prime Minister Theresa May in Joint Press Conference, June 4, 2019, https://www.whitehousegov/briefings-statements/remarks-president-trump-prime-minister-mayjoint-press-conference/.

2 Jackson [6].

Robert Cook

r.cook@ sussex.ac.uk

Clive Webb

c.j.webb@sussex.ac.uk

1 Sussex University, Brighton, UK
} 
some government officials who feared that it would reignite the smouldering resentment of the British public over the Suez crisis 3 years earlier. As part of a secret plan hatched with Britain and France, Israel launched an invasion of the Egyptian Sinai in October 1956. This provided a pretext for its fellow conspirators to send troops to occupy the region around the Suez Canal. Eisenhower, however, had curtailed this imperialist plot by using the threat of economic sanctions to force London and Paris to withdraw their forces. In the opinion of many observers at the time and historians since, the animosities caused by the American response to the Egyptian situation represented the nadir of the transatlantic alliance. Yet when he came to Britain, it soon became clear from the huge crowds that turned out to greet him that public admiration for 'Uncle Ike' as the former Allied Supreme Commander outweighed any animosity for his actions as president. Indeed, a substantial element of the public actually supported his frustration of British foreign policy. ${ }^{3}$

In their contrasting ways, these two presidential visits show how the attitudes of the British public towards the USA since 1941 have never been in continual alignment with those of the political elite. Scholars typically periodise the history of Anglo-American relations in terms of the concurrent political administrations on either side of the Atlantic. They evaluate the relationship between the two nations on the basis of the personal and political bonds between the British prime minister and the US president. The line of a graph depicting the historical ebb and flow of Anglo-American relations would therefore dip sharply during the Heath-Nixon era but rise steeply through the Thatcher-Reagan years. But, as the presidential visits of Eisenhower and Trump demonstrate, such an evaluation on this basis is unlikely to yield an accurate understanding of the state of public opinion in either country. For example, while the Thatcher-Reagan years are often depicted as the high point of Anglo-American relations after 1945, Ronald Reagan was no hero to many Britons, not least those who opposed his policy of emplacing nuclear missiles in the UK. Prime Minister Tony Blair supported the US War on Terror and received a standing ovation in Congress for his loyal support of President George W. Bush, yet Bush was deeply unpopular in Britain and the invasion of Iraq was preceded by the largest protest rally in British history. ${ }^{4}$

Despite the use of opinion polls by some scholars, the academic literature does not systematically address the extent to which British public opinion about the USA has mapped onto diplomatic, military and economic interaction at the level of the nation-state. Since most histories of Anglo-American relations focus only on elite interaction, they rely almost exclusively on official governmental records. This, however, is to neglect the context in which politicians and diplomats operate. These state actors are themselves products of political cultures that influence their opinions and behaviour. The ways in which popular attitudes have shaped and in turn been moulded by political elites nonetheless remain seriously understudied despite the 'cultural turn' in diplomatic history that stresses the need to understand the core values that underpin interstate relations. Given the rhetorical claims that are made

\footnotetext{
3 Thorpe [14, pp. 439-41], 'Uncle Ike' [15].

4 Wallace and Phillips [16].
}

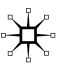


about the common identity that binds Britain and the United States together in a uniquely 'special relationship', the inattention to this issue is unfortunate. ${ }^{5}$

Scholars have not entirely neglected British attitudes towards the United States outside the realms of trade, diplomacy and warfare. The censorious tone of nineteenth-century travel accounts such as Frances Trollope's The Domestic Manners of the Americans (1832) and Charles Dickens' American Notes for General Circulation (1842) provides historians with a sharp insight into the cultural condescension of Britons towards the fledgling American republic. Scholars have also assessed grassroots support in Britain for the Union and the abolition of slavery during the American Civil War, contrasting it with the conservative elite's championing of the breakaway southern Confederacy. ${ }^{6}$ Public responses to the presence in Britain of 1.6 million American servicemen and women during the Second World War have also been extensively documented by historians. ${ }^{7}$

Scholarship on popular attitudes during the post-war period is, by contrast, surprisingly thin. What literature there is tends to focus narrowly on the issue of the Americanisation of British institutions, language and culture. ${ }^{8}$ Historians have also shown the need to caution against the use of such a monolithic term as 'British opinion'. Party political affiliation, for instance, is not a precise determinant of attitudes towards the USA. Hence, the leadership of the Labour Party has, with the exception of very recent history, tended to be more Atlanticist than the grassroots membership. ${ }^{9}$ Yet there is much more we need to learn. Since opinion poll data seldom provides a demographic profile of respondents, it affords little perspective on differences in opinion shaped by age, gender, class, race and ethnicity. Providing a more nuanced portrait of British public opinion will allow us to move beyond broad generalisations. While it is important to determine more precisely what the British people believe about the United States, we also need to assess how they came to hold these opinions. In some cases, Britons base their views on news reportage of events on the other side of the Atlantic. However, in other instances, their conception of the United States owes more to the way it is represented in the American popular culture that floods this country. Ascertaining the sources on which Britons base their opinions about the United States will enable us to assess whether rational fact or emotional feeling is the greater influence.

The articles in this special issue deepen our understanding of continuity and change in British attitudes towards the United States from the Second World War to the present day. As well as helping to gauge the relationship between public opinion and government policy, they assess the ways in which ordinary Britons have comprehended Americans as a people and the United States as a polity. The focus is not only on the USA as a geographic entity but also as a place of the imagination.

\footnotetext{
5 Iriye [5].

${ }^{6}$ Of the many books written on this subject, two of the best are Blackett [1], and O'Connor [11].

7 Longmate [8], Gardiner [2], Reynolds [13].

${ }^{8}$ Horn [4], Malchow [10], Glancy [3]. A notable exception is John F. Lyons [9]. This special issue builds on the foundation laid by that important book.

9 Pelling [12], Jones [7].
} 
Collectively, the articles reveal that British attitudes have been as complicated and contradictory as the United States itself. Britons have frequently criticised what they see as the many flaws of the United States while simultaneously gorging themselves on the soft fruits of American mass production from high street fashions to Hollywood films. They have also looked expectantly to the United States for military support and financial aid but often mistrusted American motives when it has been forthcoming.

The interdisciplinary collection of articles that follows covers an array of subjects. James Cronin's opening essay focuses on intergovernmental relations since 1945. He argues that scholars of Anglo-American relations in the modern era must be attentive to the interplay of historical contingency, leaders' actions and public opinion. While Cronin notes that a strong sense of shared culture has long existed between Americans and Britons, he argues that this sense only 'bore fruit in policy coordination when interests were shared and intense'. 'Shared cultures and shared values, to put it slightly differently', posits Cronin, 'are best understood in this context as permissive factors that allowed more active cooperation when interests demanded it. They do not determine policy and shape actions'. Clive Webb's investigation of British public attitudes towards the USA mines the rich seam of the Mass-Observation archive. It not only demonstrates the diversity (and at times hostile nature) of those attitudes, but also corroborates James Cronin's contention that many Britons possess a remarkably well-informed and clear-eyed understanding of the 'special relationship'. Sylvia Ellis's essay on British attitudes to the escalating American war in Vietnam in the 1960s underscores this latter insight and in doing so confirms that UK politicians can, in certain contexts at least, be acutely sensitive to shifts in domestic public opinion about the United States. Aware that the majority of ordinary Britons were opposed to significant military support for the United States in Indochina, Prime Minister Harold Wilson resisted intense pressure by President Lyndon Johnson to signal clearly his government's backing for conflict escalation.

The fourth, fifth and sixth essays in this special edition probe the social and cultural dimensions of the special relationship. Lucy Bland's work sheds light on an understudied topic in Anglo-American relations-the efforts of black Britons to trace and contact their African American fathers, soldiers in the US armed forces in Second World War, long after those parents had returned to the United States. In charting the difficulty of those efforts, she highlights the racism of the UK and US authorities and many white Britons. The latter often welcomed African American troops in 1940s and were subsequently critical of the United States during the civil rights era. However, opposition to race mixing was deeply rooted on both sides of the Atlantic in the mid-twentieth century and racism, manifestly, was not the sole preserve of governing elites. Sam Edwards' essay makes a strong case for regarding filmic depictions of the 'friendly invasion' preceding D-Day as a principal source and indicator of British public opinion on the United States. Since the 1940s, he contends, such movies have constituted 'widely disseminated cultural texts in which those issues at the very centre of Anglo-American relations-power, control, constructions of masculinity and femininity - are imagined, projected and examined'. If ordinary Britons possess a relatively sophisticated understanding of the USA and of the UK's relationship to its hegemonic ally, historians can ill afford to neglect 
the contribution thereto of cultural products like Hollywood movies. Steve Marsh's concluding piece explains the failure of an attempt by President Barack Obama and Prime Minister David Cameron in 2011 to rebrand the Anglo-American connection as 'the essential relationship'. Tellingly, he locates the chief source of that failure in precisely the kind of cultural connections discussed by Edwards. 'Modern communication systems', writes Marsh, 'compress time and space such that Anglo-American peoples can develop a greater sense of proximity than ever before. They might even acquire a common heritage and shared memories with people they have no former connection to. Not only does all of this reinforce many (but, clearly, not all) Britons' sense of affiliation with the US, but it also helps British and American societies to develop broadly in step as they respond to common challenges and shared opportunities'.

Together, these articles provide a rich, collective portrait of British public opinion on the United States since 1941 as well as critical insights into the constant ebb and flow of the putative special relationship and the linkages between public opinion and the making of foreign policy. Tested as Anglo-American relations are bound to be in the lowering future, it seems unlikely on the basis of the evidence presented here-of the importance of perceived self-interest at the governmental level and of the conflicted nature of British public opinion about America and Americans-that debate over this complex and evolving transatlantic connection will end any time soon.

This special issue stems from a symposium on British views of the United States held at the University of Sussex in November 2018. The editors are thankful to the US Embassy in London for funding that made that event possible.

\section{References}

1. Blackett, R.J.M. 2001. Divided Hearts: Britain and the American Civil War. Baton Rouge: Louisiana State University Press.

2. Gardiner, Juliet. 1992. Over Here: The GIs in Wartime Britain. London: Collins \& Brown.

3. Glancy, Mark. 2014. Hollywood and the Americanization of Britain: From the 1920s to the Present. London: I. B. Tauris.

4. Horn, Adrian. 2011. Juke Box Britain: Americanisation and Youth Culture, 1945-60. Manchester: Manchester University Press.

5. Iriye, Akira. 1990. Culture. Journal of American History 77(1): 99-107.

6. Jackson, Marie. 2019. Trump UK Visit: Protesters Mix Humour and Expletives to Make Their Point. BBC News, 4 June 2019, https://www.bbc.co.uk/news/uk-48517606.

7. Jones, Peter. 1997. America and the British Labour Party: The Special Relationship at Work. London: Tauris.

8. Longmate, Norman. 1975. The GI's: The Americans in Britain, 1942-1945. London: Hutchinson.

9. Lyons, John F. 2013. America in the British Imagination: 1945 to the Present. New York: Palgrave Macmillan.

10. Malchow, H.L. 2011. Special Relations: The Americanization of Britain. Stanford, CA: Stanford University Press.

11. O'Connor, Peter. 2017. American Sectionalism in the British Mind, 1832-1863. Baton Rouge: Louisiana State University Press. 
12. Pelling, Henry. 1956. America and the British Left from Bright to Bevan. London: Adam \& Charles Black.

13. Reynolds, David. 1995. Rich Relations: The American Occupation of Britain, 1942-1945. London: HarperCollins.

14. Thorpe, D.J. 2010. Supermac: The Life of Harold Macmillan. London: Chatto \& Windus.

15. 'Uncle Ike'. 1959. Guardian, September 1, 1959.

16. Wallace, William, and Christopher Phillips. 2009. Reassessing the Special Relationship. International Affairs 85(2): 274-278.

Publisher's Note Springer Nature remains neutral with regard to jurisdictional claims in published maps and institutional affiliations.

Clive Webb is Professor of Modern American History at the University of Sussex. Webb is author most recently (with William D. Carrigan) of Forgotten Dead: Mob Violence Against Mexicans in the United States 1848-1928 (Oxford University Press, 2013). He is currently the recipient of a Leverhulme Major Fellowship.

Robert Cook is Professor of American History at the University of Sussex. A specialist on the American Civil War, his publications include Troubled Commemoration: The American Civil War Centennial, 1961-1965 (Louisiana State University Press, 2007), Civil War Senator: William Pitt Fessenden and the Fight to Save the American Republic (Louisiana State University Press, 2011) and Civil War Memories: Contesting the Past in the United States since 1865 (Johns Hopkins University Press, 2017). 